
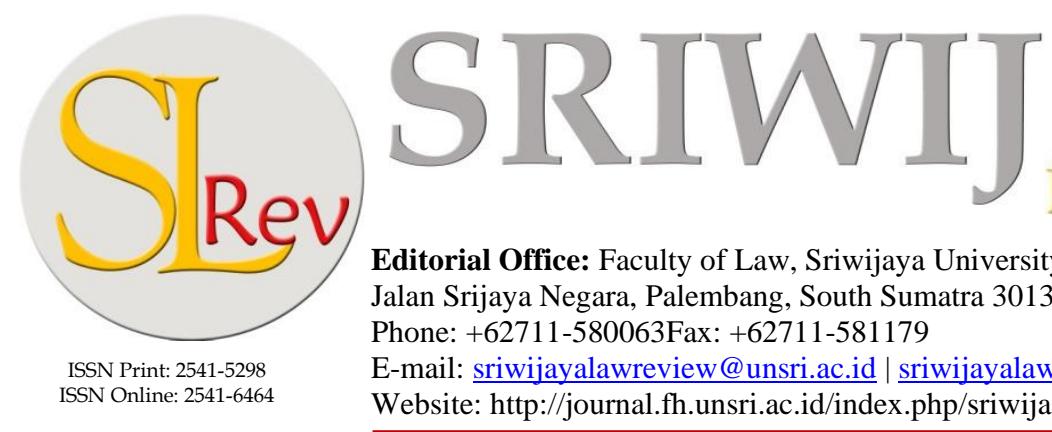

Editorial Office: Faculty of Law, Sriwijaya University

Jalan Srijaya Negara, Palembang, South Sumatra 30139, Indonesia

Phone: +62711-580063Fax: +62711-581179

E-mail: sriwijayalawreview@unsri.ac.id | sriwijayalawreview@ gmail.com

Website: http://journal.fh.unsri.ac.id/index.php/sriwijayalawreview

\title{
The Fishing Rights Conflict in the South China Sea between Vietnam and China
}

\author{
Mohammad Hazyar Arumbinang, ${ }^{\mathrm{a}}$ Yordan Gunawan, ${ }^{\mathrm{b}}$ and Rizaldy Anggriawan ${ }^{\mathrm{c}}$
}

a School of Law, University of Melbourne, Melbourne, Australia. E-mail: marumbinang@student.unimelb.edu.au

$b^{*}$ Corresponding Author. Faculty of Law, Universitas Muhammadiyah Yogyakarta, Yogyakarta, Indonesia. E-mail: yordangunawan@umy.ac.id

c. Department of Financial and Economic Law, Asia University Taiwan, Taichung, Taiwan. Email: 108136043@live.asia.edu.tw

\begin{tabular}{|c|c|}
\hline Article & Abstract \\
\hline Keywords: & This research aims to understand and clarify the international legal perspec- \\
\hline Fishing Rights; Interna- & $\begin{array}{l}\text { tive relating to the current dispute and how they are resolved according to } \\
\text { international law between Vietnam and China over fishing rights in the }\end{array}$ \\
\hline Line; South China Sea. & $\begin{array}{l}\text { South China Sea. This paper has adopted a normative legal research with a } \\
\text { statutory and historical approaches. The data will be analysed by using de- }\end{array}$ \\
\hline Article History & $\begin{array}{l}\text { scriptive-analytical analysis. This paper reveals that there are two legal is- } \\
\text { sues in the fishing rights conflict between Vietnam and China. First is the }\end{array}$ \\
\hline & ity of the Nine-dashed Line by China to claim the disputed water. Sec- \\
\hline $\begin{array}{l}\text { Reviewed: Jul 23, 2021; } \\
\text { Accepted: Jul 29, 2021: }\end{array}$ & ond, the legality of unilateral fishing ban policy by China over the disputed \\
\hline Published: Jul 31, 2021. & $\begin{array}{l}\text { water, which both has no legality under international law. Although China } \\
\text { claims over SCS using Nine-dashed Line and unilateral fishing ban policy }\end{array}$ \\
\hline & $\begin{array}{l}\text { under international law has no legal basis, the dispute over SCS including } \\
\text { fishing rights continued until today. The solutions offered to solve these }\end{array}$ \\
\hline $\begin{array}{l}\text { 10.28946/slrev.Vol5.Iss2. } \\
\text { 875pp205-217 }\end{array}$ & $\begin{array}{l}\text { problems include a resolution on SCS dispute must be made legally and di- } \\
\text { plomacy to build confidence-building measures. Ideally, both states should } \\
\text { honour the accepted negotiation steps to agree upon compensation for the } \\
\text { effects of the disputes and be sincere and earnest in their attempts and com- } \\
\text { mitment to resolving their dispute. }\end{array}$ \\
\hline \multicolumn{2}{|c|}{$\begin{array}{l}\text { (02021; This is an Open Access Research distributed under the term of the Creative Commons Attribution } \\
\text { License (https://Creativecommons.org/licences/by/4.0), which permits unrestricted use, distribution, and repro- } \\
\text { duction in any medium, provided the original works is properly cited. }\end{array}$} \\
\hline
\end{tabular}

\section{INTRODUCTION}

The South China Sea, as disputed water, is the focus of a variety of disputes due to overlapping claims made by the countries around it. Most of the claims are based on historical justifications relating to the countries involved. This turbulence causes uncertainty in the control of the South 
China Sea (abbreviated as the SCS). Each contesting country makes claims based on historical reasons, a situation resulting in overlapping claims regarding the SCS. ${ }^{1}$

Fishing rights have become one of the disputes that have grown around the SCS due to some countries which neighbour the SCS affirming their exclusive rights to fish in the SCS. For instance, Vietnam claims that their exclusive right is within 200 nautical miles of their coast. ${ }^{2}$ On the other hand, the right over fisheries in the SCS asserted by the People's Republic of China (hereafter abbreviated to China) was more significant than 200 nautical miles from that nation's coast, an outcome achieved by the use of the "U-shaped line". 3

China and Vietnam are two countries that have uneasy bilateral relations. Tensions between the two countries occur because both are equally active in claiming the Spratly and Paracel islands, which are the main targets of the conflict in the region. The considerable energy resources speculated to be located in the SCS have sparked tensions between Vietnam and China. In addition, the two respective islands are used as markers of (a) the territorial limits of the claiming country, (b) free navigation access around the islands, and (c) the potential fish stocks in the waters around the two islands. ${ }^{4}$

China recently issued a regulation, the China Fishing Ban, to be applied to the SCS. Vietnam has firmly rejected this fishing ban made by China, which it sees as China's unilateral decision regarding banning some fishing activities in the SCS from 1 May to 16 August 2020. The Vietnamese government not only allows Vietnamese fishers to continue operating around the disputed Paracel islands, even though China unilaterally enforces a ban on fishing in the SCS but also directs its provincial governments to support Vietnamese fishers at sea. ${ }^{5}$ Many of the actions conducted by China in banning fishing activities in the SCS have provoked adverse reactions from Vietnam.

This research tries to find what are the legal issues in the fishing rights conflict between Vietnam and China and how they resolved according to international law. This paper will discuss the tensions between Vietnam and China, the fishing ban by China, and describing fishing rights under international law using the United Convention for the Law of the Sea, China's actions, and dispute settlement. This article also reveals problems in fishing rights between Vietnam and China over SCS under international law and provides possible solutions to these issues.

\section{RESEARCH METHODS}

This paper is based on normative legal research, using an international law perspective in relation to the fight for fishing rights in the disputed waters of the SCS. There are several approaches to writing legal research in order to obtain information relating to various aspects of the issue being discussed. In this research, the authors use a statutory approach and historical approach,

\footnotetext{
Mohan Malik, "Historical Fiction: China’s South China Sea Claims,” World Affairs 176, no. 1 (2013): 87.

2 Gregory B. Poling, The South China Sea in Focus: Clarifying the Limits of Maritime Dispute (London: Rowman \& Littlefield, 2013).

3 Keyuan Zou and Xinchang Liu, "Skip Nav Destination Article Navigation The Legal Status of the U-Shaped Line in the South China Sea and Its Legal Implications for Sovereignty, Sovereign Rights and Maritime Jurisdiction," Chinese Journal of International Law 14, no. 1 (2015): 73.

4 Ralf Emmers, ASEAN and the Institutionalisation of East Asia (London: Routledge, 2012).

5 Mai Ngoc Chau, "Vietnam Rejects China's South China Sea Fishing Ban," Blommberg Quint, 2020, https://www.bloombergquint.com/global-economics/vietnam-rejects-china-s-south-china-sea-fishing-ban.
} 
especially when dealing with the issue of fishing rights in the SCS. ${ }^{6}$ The data collection method in this research will be through a library search by accessing a range of relevant literature sources. The data will be collected by reading, analysing and summarising related documents, such as conventions, laws books, legal journals, and other sources associated with the central issue of this research. The data will be analysed by using descriptive-analytical analysis. Furthermore, the data will also be connected with legal principles, conventions, and other related rules, all under the 'umbrella' of juridical thinking.

\section{ANALYSIS AND DISCUSSION}

\section{Fishing Dispute in the South China Sea}

Some disputes between China and other countries are happening around and relate to the South China Sea. The most substantial dispute is about the right to catch fish because most countries bordering the SCS confirm that they have exclusive rights to fish in that part of the region. In this case, China also stated that it has the right to use or exploit fishery resources around the SCS; but not only in waters within 200 nautical miles from the mainland coast and the Paracel Islands. By using a 'U-shaped line', it is known that China has reached the boundary of an exclusive economic zone (EEZ), which might potentially be generated from its land and also on any island around the SCS that asserts its sovereignty. ${ }^{7}$

In the SCS, aside from tensions arising from interrelated assertions between disputing countries that until now cannot be stopped, there have also been unsatisfactory developments, especially regarding relations between Vietnam and China. ${ }^{8}$ Moreover, some Chinese behaviour, such as increasing numbers of fishing boats and fishing activities carried out by Chinese ships in Vietnamese waters, finally rendered all the results of their bilateral meetings valueless. Four bilateral meetings between Vietnam and China had already taken place at the beginning of 2011, whose purpose was to discuss their different perspectives regarding the conflict in the SCS. However, some incidents still happened, which served to worsen the bilateral situation. Wire cutting by China to Vietnam's oil exploration sites in the SCS created tension between the two nations. Furthermore, Vietnam decides to improve their military presence in the SCS. ${ }^{9}$

Some countries joined the SCS conflicts by using their histories and geographical basis in fighting for the right to claim 'ownership of land and sea areas in the SCS. For example, China used its historical basis to claims some islands in the SCS. China claimed that for 2000 years, the Paracel and Spratly islands in the disputed area were China's own; then, in 1947, the "Nine-Dash Line" was made. The Chinese government decided to create a map of China's sovereignty in the SCS to show that China had 'ownership' of those territories. The dispute in the SCS regarding territoriality means that disputes refer to and involve the land areas and territorial sea areas in the Paracel and Spratly islands. ${ }^{10}$

Peter Mahmud Marzuki, Penelitian Hukum, Vol. 2 (Jakarta: Kencana, 2008).

China's Exclusive Economic Zone and Continental Shelf Act 1998.

8 Leszek Buszynski, "The South China Sea: Oil, Maritime Claims, and U.S.-China Strategic Rivalry," The Washington Quarterly 35, no. 2 (2012): 139-56.

9 I Nyoman Sudira, "The South China Sea: Oil, Maritime Claims, and U.S.-China Strategic Rivalry," International Relations Scientific Journal 10, no. 2 (2014): 143.

10 Poltak Partogi Nainggolan, South China Sea Conflict and Its Implications for Regions (Jakarta: P3DI Secretariat General of the Republic of Indonesia Parliament, 2013). 
Additionally, the SCS is covering potential sources of mineral wealth. Chinese officials estimate that oil reserves, specifically around the Paracel and Spratly islands, are 213 billion barrels, or 10 times the U.S. reserves. However, U.S. scientists have estimated the amount of oil to be 'only' 28 billion barrels. ${ }^{11}$ The SCS is also one of the wealthiest fishing regions globally, which provides for nearly $10 \%$ of global fish consumption and is an essential component of global food security. Therefore, many countries fight over this region. ${ }^{12}$

In recent years, economic pressure leading to a willingness to expand the fishing area has led to the process of 'coastal guarding' conducted in the SCS. ${ }^{13}$ China used its maritime law enforcement agencies and fishers as tools to strengthen that nation's claims. It is part of China's strategy to show that it has the right to 'own' the area. Not only by using traditional fishers, fishing vessels from any part of China are also being asked to go to the disputed waters of the SCS. Overlapping law enforcements areas, together with a lack of cooperative management in the SCS, negatively affect the marine environment and fisheries' health in the SCS. ${ }^{14}$

In addition, many fishers or boats from different competing nations often meet in the oceans. These encounters at sea make the intensification of minor incidents or clashes more likely, at times creating the perplexing problem of providing humanitarian treatment for injured fishers. When behaviour at sea becomes unpredictable, maritime actors are faced with more significant levels of uncertainty in their own assessment making when they encounter fishing vessels or maritime law enforcement vessels from other countries. ${ }^{15}$

In recent years, the role of frontline maritime law enforcement vessels in the contention of sovereignty assertions in the SCS dispute has been augmented. As a result, law enforcement and the conduct of fishing vessels in the SCS are becoming progressively more politicised and volatile. Incidents at sea involving maritime law enforcement and fishing vessels from various claimant countries are now common occurrences and sometimes result in severe, damagingly adverse outcomes. ${ }^{16}$

\section{China's Fishing Ban in the South China Sea}

The banning of fishing activities, as implemented by China, started in $1999 .{ }^{17}$ The one-sided annual fishing ban imposed by China is attracting international attention. China is creating the policy in the disputed area between China and Vietnam without the consent of Vietnam. The policy is applied in the territorial claims areas that overlap with Vietnam in the northern part of the SCS, involving approximately 128,000 square $\mathrm{km}$. Initially, the ban was arranged for two months. However, since 2009, the Chinese authorities have made a move that aimed to preserve the marine reserves. The ban has been prolonged to 2.5 months, from 16 May to 1 August every

11 Nainggolan.

2 Nainggolan.

13 Zhang Hongzhou and Sam Betemen, "Fishing Militia, the Securitization of Fishery and the South China Sea Dispute," Contemporary Southeast Asia 39, no. 2 (2017): 288-314.

14 U. Rashid Sumaila and William W. L. Cheung, Boom or Bust: The Future of Fish in the South China Sea (Vancouver: University of British Columbia, 2015).

15 Amanda Hsiao, "Opportunities for Fisheries Enforcement Cooperation in the South China Sea," Marine Policy 121 (2020): 2.

16 Hsiao.

17 Xinyi Song et al., "Determining the Optimal Premium for ADR Implementation Insurance in Construction Dispute Resolution," Journal of Management in Engineering 30, no. 4 (2014): 12. 
year. Nevertheless, despite the apparently 'good intentions', some international scholars believe that the actions taken by China are part of a strategy to claim sovereignty over the area.

China's unilateral decision places Vietnam's government in a difficult situation. It also endangers the fishermen's living and working conditions; Vietnam has to protect access to their sea stock to maintain their industry. Suppose the fishermen are in danger and face the possibility of being caught or seized. In that case, such a situation is a worry for Vietnam's government regarding the well-being of their citizens and the sustainability of their fishing industry. ${ }^{18}$ Furthermore, Vietnamese fishers are in a dilemma; do they choose to stay in port or continue to fish generally in the SCS?

There are still many of them who are deciding to continue their activities in order to preserve their livelihoods. Their decisions are not forced by the Vietnam government for political reasons but are based on the necessity to meet their needs, which can be achieved from the SCS. However, in the current situation, many fishermen choose to remain in port and not fish to avoid being caught and having their boats and nets confiscated. As a solution for Vietnamese fishers, they decided to fish in the waters nearest to their coast and avoid the disputed area. However, their fishing haul does not match their catch when fishing further out in the SCS. China's fishing ban policy not only affects the bilateral relationship between China and Vietnam, but it is also directly impacting the Vietnamese fishermen and their families well-being, which depends on fishing. Therefore, in order to prevent environmental and ecological instability caused by illegal, unreported and unregulated fishing (hereafter abbreviated as IIU fishing), as well as overfishing, in addition to preventing fishing conflicts due to increased competition for limited fish stocks, the regional countries' fishing industries and their activities need to be controlled and even reduced.

The fundamental challenge facing the SCS's fisheries is that too many people depend on limited fish stocks for food and primary sources of income, which is further complicated by unresolved 'rights' areas and sea boundary disputes. ${ }^{19}$ The SCS conflict between China and the ASEAN countries regarding the SCS coasts is a threat to the security of the ASEAN community. This paper's authors noted that Karl Deutch's theory identifies three things that need to be considered in shaping a secure society: (1) that policymakers and the public should stop contemplating the possibility of war, (2) the state stops allocating resources, and (3) there is strict acceptance of, and compliance with, specific rules and agreements if the collective goals of the involved units are not aligned. ${ }^{20}$

Since the beginning of 2011, escalation of tensions in the SCS has increased due to: (1) competition over marine resources, (2) claims of increasing sovereignty, and (3) increasingly aggressive Chinese tactics. ${ }^{21}$ Although China has committed to supporting peace and stability in the region, in reality, this Chinese rhetoric is not reflected in its actions in the SCS; actions which

18 Ha Anh Tuan, "The Tragedy of Vietnamese Fishermen: The Forgotten Faces of Territorial Disputes in the South China Sea," Asia Journal of Global Studies 5, no. 2 (2013): 94-107.

19 Hongzhou Zhang, "Fisheries Cooperation in the South China Sea: Evaluating the Options," Marine Policy 89 (2018): 67-76.

20 Agus Haryanto and Arief Bakhtiar, "Sengketa Laut Tiongkok Selatan: Ancaman Bagi Komunitas Keamanan ASEAN?," Global \& Strategi 9, no. 2 (2015): 277-96.

21 Ian Storey, "Hardening Positions over Dangerous Grounds: Recent Developments in the South China Sea Dispute," CSIS Center for Strategic \& International Studies, 2011, 20-21. 
have shown an increasingly aggressive tendency from 2011. Anxiety levels from some 'claiming' countries involved in SCS disputes have also heightened due to: (1) increased Chinese nationalism, (2) China's increased military capabilities and (3) China's assertive attitude in the SCS. There are three key points that illustrate China's insistent strategies in the SCS:

1. The expulsion of an energy company ship which explored in the EEZ region and of a Philippine ship near Reed Bank by a Chinese ship and the cable cutting of seismic equipment for the Vietnam Petro ship and Viking 2 in the EEZ Vietnam region by a Chinese ship;

2. China has tightened the implementation of the unilateral annual fishing ban in the north of the SCS and has captured more than a dozen Vietnamese fishing vessels and fired warning shots at Philippine fishing vessels; and

3. Chinese ships' crews have unloaded construction materials on Amy Douglas Reef in the Philippines EEZ area and placed markers on the Reed Bank and Boxall Reef. ${ }^{22}$

China claims its sovereignty over the four island groups in the SCS and surrounding seas based on three elements, namely 1) historical rights, which include discovery, naming, sustainable use of names, and actions of protest and resistance to foreign invasion; 2) administration via an ongoing administrative authority; and 3) recognition of the sovereignty of China from the international community and even from some other claiming countries. However, China claims its sovereignty over the four island groups in the SCS and surrounding seas lack of legal basis. There was no evidence that China had historically exercised exclusive control over the islands and waters of the SCS (disputed water). Regardless, any pre-existing, historic Chinese rights were extinguished to the extent they were incompatible with the UNCLOS 1982. Therefore, all claims by China over SCS and their military presence in the disputed water only because their unilateral claims under international law are not legal. Although international law seems like the position of China in claiming the SCS is weak or has no legal basis, China still deployed their military and issued policy on SCS, including a fishing ban to show and maintain their unilateral claims over disputed water. Meanwhile, to resolve this dispute, it is recommended that all parties work together in finding a peaceful resolution based on four principles: 1) Peaceful management of the sea; 2) Step-by-step efforts; 3) Fair and balanced distribution of profits; and 4) Environment-friendly exploration. ${ }^{23}$

Both China and Vietnam filed claims for rights to the SCS. However, it should be noted that China has an ever-growing military presence in the area, and Vietnam has pragmatically recognised the SCS as belonging to China. Both countries agreed not to challenge each other over the dispute that occurred because of claiming fishing and other rights relating to the SCS; both nations promised 'not to complicate matters.' However, after various disputes arose between China and Vietnam, China made yet another unilateral decision that various neighbouring countries rejected, including Vietnam. The unilateral decision was for China to ban fishers from fishing in the summer (August 2020). Because Vietnam has the right to access the SCS, as agreed, it strongly rejected the unilateral decisions made by China. The Vietnamese government insisted that Vietnamese fishers had full rights to catch fish in the SCS, even in the summer.

22 Storey.

23 Faudzan Farhana, "Memahami Perspektif Tiongkok Dalam Upaya Penyelesaian Sengketa Laut Cina Selatan," Jurnal Penelitian Politik 11, no. 1 (2014): 167-80. 


\section{China-Vietnam Tension in the South China Sea}

The tension between China and Vietnam can be seen from the actions taken by China towards Vietnam regarding the issue of fishing rights in the SCS. Both countries are actively struggling with their rights regarding the Paracel and Spratly islands, which are both located in the SCS. This issue is highly complex and therefore extremely difficult to resolve, as it has become an issue that involves claims by many ASEAN countries. The disputed area occupies a strategic location due to the richness of the fishing ground. Many experts believe that the SCS is covering significant hydrocarbon reserves, as mentioned above. ${ }^{24}$ Furthermore, China and Vietnam are both claiming 'ownership' of the Paracel and Spratly Island groups. Nevertheless, according to China's nine-dash line theory, Paracel is 'owned' by China. In addition, the quantity of China's military equipment is increasing, which is in line with their increasing number of patrol activities in the SCS area. ${ }^{25}$ However, in December 2008, China and Vietnam agreed to start a bilateral discussion of marine issues. The main topic to be discussed was the "fundamental guiding principles" that would form an agreed outline for resolving specific problems.

The confidential discussions were actually started in early 2010. According to sources from the Vietnamese Ministry of Foreign Affairs, the disputed parties agreed to resolve their disparities "through peaceful negotiations" also "to refrain from any actions to complicate the situation, violence or threat of using force". However, tensions are expected to increase in the SCS because as recently as mid-2020, China imposed an annual summer ban on fishing in the disputed areas of the SCS. The policy ignited protests from neighbouring countries.

The latest news says fishing activities in waters claimed by China above the 12th parallel will be banned. These areas include the Scarborough Shoal, Paracel Islands, and Tonkin Bay, which China states will be designated as conservation reserves. The ban will take effect from noon on 1 May to 16 August 2020. China even insisted their coast guard service would take "strict measures" to stop "illegal fishing activities".

In response, fishing communities in Vietnam and the Philippines have urged their governments to take a firm stand. On 8 May 2020, the Vietnamese foreign ministry rejected "unilateral decisions". Vietnam asked China not 'to complicate' the situation in the SCS. According to the Vietnamese government, Vietnamese fishers have full rights to catch fish in the waters under their sovereignty.

\section{International Law Perspective on Fishing Rights}

The international law of the sea regulates significant matters related to the application of state sovereignty in sea areas. These matters include: (1) the rights and obligations of the state in territorial sea areas, (2) exclusive economic zones and in international waters, (3) traffic and conservation of marine and oceanic ecosystems, all three of which are regulated by international sea law. Thus, a country's sovereignty over its territorial waters is informed by norms that contain both rights and obligations. One of the rights that is closely related to the state's sovereignty in its territorial waters is the right of that state to explore and exploit natural resources in the appropri-

$24 \mathrm{Mu}$ Ramkumar and M. Santosh, "Hydrocarbon Reserves of the South China Sea: Implications for Regional Energy Security," Energy Geoscience, 2020, 6.

25 Zhiguo Gao and Bing Bing Jia, "The Nine-Dash Line in the South China Sea: History," American Society of International Law 107, no. 1 (2013): 98-124. 
ate sea area. This right includes the country's territorial sea area and/or island waters. In addition, the concepts of (a) exclusive economic zones and (b) continental shelf areas in territorial waters that are regulated in international maritime law enable a country to exercise its right to exploit natural resources in these areas. ${ }^{26}$ Furthermore, regarding the international law perspective on the issue of the fishing rights dispute (some observers may say 'fight') between Vietnam and China, there are several points that could be discussed further.

\section{Traditional Fishing Grounds Based on the UNCLOS 1982}

As a comprehensive legal basis on the international law of the sea, UNCLOS 1982 (the United Nations Convention on the Law of the Sea) can accommodate the interests of the participating states and non-participating countries in determining the law of the sea. An international agreement was reached in Montego Bay, Jamaica, on 10 December 1982. This convention, signed by 119 countries, consisted of 17 parts, 320 articles and 9 Annexes. By 2004 the convention had been ratified by 145 countries. ${ }^{27}$

UNCLOS 1982 is an international agreement involving rules that focus on the law of the sea, including regulating access to and use of the seabed area, the ocean floor and the land beneath it. Also addressed are the rights and obligations of states to manage and utilise all marine resources for all humanity in a responsible manner. The provisions of this convention concern: (1) the limits of the jurisdiction of a state at sea and in the air or the state's exclusive economic zone (EEZ), (2) the concept of the archipelagic state, (3) navigation, protection and maintenance of the marine environment, (4) scientific research, (5) seabed mining and exploitation other than from non-biological sources, as well as (6) provisions relating to the settlement of disputes resulting from oversea conflict areas. Also included are provisions relating to the critical issue of traditional fishing grounds. Considering this broad scope, many scholars believe that the 1982 UNCLOS is the complete international convention yet realised and is adhered to in support of international sea law.

The EEZ concept, which involves an exclusive zone permitting a coastal country to enjoy the territorial waters included in its jurisdiction, as stated in Article 57 of UNCLOS, has several provisions that can be analysed: ${ }^{28}$ a) An EEZ involves the special rights of the coastal states, which include the rights and jurisdiction and other immunities that are subject to the sovereignty of the coastal states through certain agreements; b) Sovereign rights to explore, exploit, conserve, and manage all-natural resources of the seabed and the above waters. The same applies to all activities aimed at the economic exploitation of the zone (such as energy, current and windbased electricity production); c) Jurisdiction, as determined in this convention, for the establishment and use of artificial islands, scientific research and the protection of the marine environment; and d) Rights and obligations as stipulated in the convention.

As stated in the EEZ concept there are rights enjoyed by coastal and non-coastal countries around an EEZ, but in the international interest there are exceptions to rights from other coun-

\footnotetext{
26 Ian Brownlie, "Principles of Public International Law," VRU Verfassung Und Recht in Ubersee 14, no. 1 (1980): 92-93.

27 Nurfaika Ishak and Siti Fatimah, "Pengawasan Penangkapan Ikan Di Zona Ekonomi Eksklusif Indonesia Dalam Membangun Poros Maritim Indonesia," Wacana Hukum 25, no. 2 (2019): 59-77.

28 Louis B Sohn et al., Cases and Materials on the Law of the Sea, 2nd ed. (Leiden: Nijhoff, 2014).
} 
tries that are not included in an EEZ territory, as stated in Article 58, namely: ${ }^{29}$ a) freedom of shipping and flight; and b) freedom to lay cables under the sea and pipes and other uses that are justified internationally, such as those relating to the linkage and operation of ships, aircraft, marine cables and pipes.

Related to historical traditional fishing rights, based on Article 51, (1), UNCLOS 1982 stipulates that an archipelagic country must respect existing agreements with other countries and must recognise traditional fishing rights and other legitimate activities of neighbouring countries. The terms and conditions for exercising such rights and activities, including their nature, scope and area, shall be governed by bilateral agreements between the two countries concerned.

Jose Manuel Sobrino explained explicitly that the concept of traditional fishing grounds is: (a) to provide flexibility/permission between the coastal state and the recipient country to determine the place and area of fishing, (b) the flexibility of fishing without being blocked by coastal state authorities, and (c) other opportunities that are permitted between the two countries. Thus, exclusive rights that were previously absolutely in the hands of the coastal state will be delegated to the state that enjoys rights in the traditional fishing ground. ${ }^{30}$

In addition to UNCLOS 1982, other more technical legal provisions govern IUU fishing as international legal instrumentation for violating a nation's historical traditional fishing right claim. Based on the provisions of Agenda-21 Johannesburg, section 17.3 states that the countries on the face of the earth must strive to safeguard EEZ regions in the framework of regulation and the development of marine aquaculture. This endeavour is necessary in order to avoid misuse of marine resource management, one potential example being the issue of IUU fishing. It should be stressed that the provision also provides a guideline for states to make national regulations regarding the management and utilisation of marine products. ${ }^{31}$

\section{Traditional Fishing Rights under the UNCLOS 1982}

The international law of the sea has not comprehensively governed traditional fishing rights. The right to fish is traditionally implicitly mentioned in Article 47, (6) of UNCLOS 1982, where the rights and interests that have traditionally been exercised by a state bordering (one of) the archipelagic waters of an archipelagic state have been determined and made explicit.

In addition, Article 51 (1) of UNCLOS 1982 further addresses the issue of traditional fishing rights. Article 51 (1) of UNCLOS 1982 explains that island nations must respect agreements with other countries and recognise countries' traditional fishing rights bordering directly with zones within archipelagic waters. Furthermore, the terms and conditions for carrying out these rights and activities must be based on the state's request, a situation that is related and regulated through bilateral agreements.

Traditional fishing rights are highlighted in and based on UNCLOS 1982, where it is stated that the recognition of the 'right to fishing' is contained in Article 51, (1) of UNCLOS 1982. Important points to be noted in Article 51 are: a) it is necessary to distinguish between traditional

\footnotetext{
29 Albert Koers, Rudi Rizki, and Wahyuni Bahar, Konvensi Perserikatan Bangsa-Bangsa Tentang Hukum Laut: Suatu Ringkasan (Yogyakarta: Gadjah Mada Universitas Press, 2014).; Yordan Gunawan, Hukum Internasional: Sebuah Pengantar Modern (Yogyakarta: LP3M UMY, 2021).

30 Gemma Andreone, The Future of the Law of the Sea: Bridging Gaps Between National, Individual and Common Interests (Rome: Springer Nature, 2017).

31 Natalie Klien, Maritime Security and the Law of the Sea (London: Oxford University Press, 2010).
} 
rights to fish and traditional fishing rights; b) fishing activities must have been carried out traditionally for a long time. So, this 'right to fish' cannot be given to those who have not been fishing for a long time in these waters. The term "traditional" refers to the equipment used, the types of fish caught, and the water areas visited; c) the concept of "immediately adjacent" refers to the understanding of geographical closeness; d) the term "certain areas falling within archipelagic waters" means that the right of fishing from a neighbouring country cannot be exercised in all territorial waters of the islands, but only in the specific parts or waters agreed upon; e) the exercise of fishing rights must be regulated further through a bilateral agreement. This condition or proviso means that fishing rights cannot be exercised without a bilateral agreement with the island nations involved. Regarding the terms and conditions of how fishing rights can be implemented must be negotiated by the two countries, and f) the existence of fishing rights must be proven by neighbouring countries that make claims to these rights. Therefore, the continuation of the fishing right must be negotiated and agreed upon by the two countries concerned through a bilateral agreement. ${ }^{32}$

After UNCLOS 1982 was adopted, only three countries, Cape Verde, Indonesia, and Trinidad and Tobago, stipulated that existing agreements would be respected. Other countries did not include guarantees for the rights of other countries based on agreement. ${ }^{33}$ UNCLOS 1982 has regulated fisheries or fishing in the world's exclusive economic zones, as set out in Article 56, which states that each country has sovereign rights to explore, exploit, conserve, and manage both natural and biological resources (living resources) and non-living resources. This natural biological resource is where the fisheries sector has an essential role in the economic development of each country because it can be used as employment for the people of a country and also brings foreign exchange into the country by the export of part of its fishing catch.

Furthermore, Article 61 Paragraph (1) of UNCLOS 1982 states that coastal states must determine the allowable catch of the living resources in their exclusive economic zones. Further, in Paragraph (2), there is a warning for coastal countries to pay attention to the best scientific evidence in order to ensure proper conservation and management of fish and other marine stocks so that biological resources in exclusive economic zones are not over-exploited.

Conservation and management are designed to ensure maximum sustainable yields for the economy of fishing communities and developing countries where coastal countries must pay attention to the issues of fishing patterns, fish stocks; collaborating with international organisations at the sub-regional, regional, or global levels; and the types of fish that can be caught, relevant and up-to-date scientific information, fishing statistics, fisheries business, and international cooperation to conserve fisheries.

The recognition of traditional fishing activities is clearly the basis of the rights of other legal protections and safeguards for traditional fishers over their traditional fishing activities. According to Ellen Hey, the state has the right to all the benefits generated from the management of fisheries in its territorial waters while acknowledging the existence of fishing rights. ${ }^{34}$

32 Hasjim Djalal, Indonesia and the Law of the Sea (Jakarta: Centre for Strategic and International Studies, 1995).

33 Etty R. Agoes, "Praktik Negara-Negara Atas Konsepsi Negara Kepulauan," Indonesia Journal of International Law 1, no. 3 (2004): 462.

34 Tore Henriksen, "Promoting Sustainable Fisheries: The International Legal and Policy Framework to Combat Illegal, Unreported and Unregulated Fishing," Ocean Yearbook Online 26, no. 1 (2012): 712-20. 
Conventionally, exclusive rights to fisheries only happen in waters that edge directly onto a country's land area. Exclusive rights to fisheries are needed in order to affirm the sovereignty of a coastal state over its territorial sea because it has the aim and social obligation to defend the welfare of that country's local fishermen. Moreover, by using technology, some fishermen can indicate which is their area to fish and which one is not if the government has already acknowledged the sovereignty. With the help of technology, the fisherman will not make mistakes when attempting to understand and clearly identify their state's territory. Such a modern initiative, rather than using the historical basis to define where to catch the fish, should reduce the incidence of 'misunderstandings' with fishermen from other countries. In addition, it should be noted that historical claim-based cases are not governed as exceptions to EEZ by UNCLOS but are ruled under customary international law.

The fishing rights claims made by China seem to be based on EEZ rights and historical claims. The EEZ idea is a relatively new concept, so asserting 'rights like EEZ' under the global community's historical claims concept will not be accepted. Suppose the historical claim is against the EEZ provisions, and there is no exclusion stipulated in UNCLOS to support the historical claim. In that case, EEZ provisions will be applied to the UNCLOS parties involved.

Likewise, Article 62 of UNCLOS implementation looks like surpassing previous traditional fishing rights if other countries' EEZs are now included. Many people also debate that although EEZ is part of new legal knowledge, the concept cannot automatically eliminate existing rights because the UNCLOS does not impact the concept of historical claims with respect to EEZ. Acknowledgement is an essential aspect in the continuance of countries' rights to fish in other countries' EEZs, not by challenging whether those rights are based on a nation's history. ${ }^{35}$

China and Vietnam are both international maritime law ratified UNCLOS in 1982, so it certainly will respect the regime of maritime and sovereignty and sovereign rights of a country, but in a different application. Vietnam more consistent use of the legal basis of UNCLOS 1982 in the claim area of its territory, while the Chinese prefer the approach to history and lack of respect for international law (UNCLOS 1982) and practice.

\section{CONCLUSION}

There are two legal issues in the fishing rights conflict between Vietnam and China. First is the legality of the Nine-dashed Line by China to claim the disputed water. This claim under international law has no legal basis. Therefore, China was never in the first place to have fishing right in the disputed water. This is because SCS is not a part of the territorial waters of China. On the other hand, under international law, Vietnam enjoys and has fishing right in the disputed water. Second, the legality of unilateral fishing ban policy by China over the disputed water. Referring to the fact that China never had any legal basis for claiming the disputed water, consequently, China has no authority to rule and manage the disputed water, including issued the fishing ban policy over the disputed water. Although China claims over SCS using Nine-dashed Line and unilateral fishing ban policy under international law has no legal basis, the dispute over SCS including fishing rights continued until today.

35 Leonardo Bernard, "The Right to Fish and International Law in the South China Sea," Journal of Political Risk 4, no. 1 (2016): 37. 
Two possible solutions might be used to solve the problems. The resolution of the SCS dispute must be made legally and diplomacy to build confidence-building measures. Ideally, both states should honour the accepted negotiation steps to agree upon compensation for the effects of the disputes and be sincere and earnest in their attempts and commitment to resolving their dispute.

\section{REFERENCES}

Agoes, Etty R. "Praktik Negara-Negara Atas Konsepsi Negara Kepulauan.” Indonesia Journal of International Law 1, no. 3 (2004): 462.

Andreone, Gemma. The Future of the Law of the Sea: Bridging Gaps Between National, Individual and Common Interests. Rome: Springer Nature, 2017.

Bernard, Leonardo. "The Right to Fish and International Law in the South China Sea." Journal of Political Risk 4, no. 1 (2016): 37.

Brownlie, Ian. "Principles of Public International Law." VRU Verfassung Und Recht in Ubersee 14, no. 1 (1980): 92-93.

Buszynski, Leszek. "The South China Sea: Oil, Maritime Claims, and U.S.-China Strategic Rivalry." The Washington Quarterly 35, no. 2 (2012): 139-56.

Chau, Mai Ngoc. "Vietnam Rejects China's South China Sea Fishing Ban." Blommberg Quint, 2020. https://www.bloombergquint.com/global-economics/vietnam-rejects-china-s-southchina-sea-fishing-ban.

Djalal, Hasjim. Indonesia and the Law of the Sea. Jakarta: Centre for Strategic and International Studies, 1995.

Emmers, Ralf. ASEAN and the Institutionalisation of East Asia. London: Routledge, 2012.

Farhana, Faudzan. "Memahami Perspektif Tiongkok Dalam Upaya Penyelesaian Sengketa Laut Cina Selatan.” Jurnal Penelitian Politik 11, no. 1 (2014): 167-80.

Gao, Zhiguo, and Bing Bing Jia. "The Nine-Dash Line in the South China Sea: History." American Society of International Law 107, no. 1 (2013): 98-124.

Gunawan, Yordan. Hukum Internasional: Sebuah Pengantar Modern. Yogyakarta: LP3M UMY, 2021.

Haryanto, Agus, and Arief Bakhtiar. "Sengketa Laut Tiongkok Selatan: Ancaman Bagi Komunitas Keamanan ASEAN?” Global \& Strategi 9, no. 2 (2015): 277-96.

Henriksen, Tore. "Promoting Sustainable Fisheries: The International Legal and Policy Framework to Combat Illegal, Unreported and Unregulated Fishing." Ocean Yearbook Online 26, no. 1 (2012): 712-20.

Hongzhou, Zhang, and Sam Betemen. "Fishing Militia, the Securitization of Fishery and the South China Sea Dispute.” Contemporary Southeast Asia 39, no. 2 (2017): 288-314.

Hsiao, Amanda. "Opportunities for Fisheries Enforcement Cooperation in the South China Sea." Marine Policy 121 (2020): 2.

Ishak, Nurfaika, and Siti Fatimah. "Pengawasan Penangkapan Ikan Di Zona Ekonomi Eksklusif Indonesia Dalam Membangun Poros Maritim Indonesia.” Wacana Hukum 25, no. 2 (2019): $59-77$. 
Klien, Natalie. Maritime Security and the Law of the Sea. London: Oxford University Press, 2010.

Koers, Albert, Rudi Rizki, and Wahyuni Bahar. Konvensi Perserikatan Bangsa-Bangsa Tentang Hukum Laut: Suatu Ringkasan. Yogyakarta: Gadjah Mada Universitas Press, 2014.

Malik, Mohan. "Historical Fiction: China's South China Sea Claims." World Affairs 176, no. 1 (2013): 87.

Marzuki, Peter Mahmud. Penelitian Hukum. Vol. 2. Jakarta: Kencana, 2008.

Nainggolan, Poltak Partogi. South China Sea Conflict and Its Implications for Regions. Jakarta: P3DI Secretariat General of the Republic of Indonesia Parliament, 2013.

Poling, Gregory B. The South China Sea in Focus: Clarifying the Limits of Maritime Dispute. London: Rowman \& Littlefield, 2013.

Ramkumar, $\mathrm{Mu}$, and M. Santosh. "Hydrocarbon Reserves of the South China Sea: Implications for Regional Energy Security." Energy Geoscience, 2020, 6.

Sohn, Louis B, John Noyes, Erik Frankx, and Kristen Juras. Cases and Materials on the Law of the Sea. 2nd ed. Leiden: Nijhoff, 2014.

Song, Xinyi, Feniosky Pena-Mora, Carol C. Menassa, and Carlos A. Arboleda. "Determining the Optimal Premium for ADR Implementation Insurance in Construction Dispute Resolution." Journal of Management in Engineering 30, no. 4 (2014): 12.

Storey, Ian. "Hardening Positions over Dangerous Grounds: Recent Developments in the South China Sea Dispute." CSIS Center for Strategic \& International Studies, 2011, 20-21.

Sudira, I Nyoman. "The South China Sea: Oil, Maritime Claims, and U.S.-China Strategic Rivalry." International Relations Scientific Journal 10, no. 2 (2014): 143.

Sumaila, U. Rashid, and William W. L. Cheung. Boom or Bust: The Future of Fish in the South China Sea. Vancouver: University of British Columbia, 2015.

Tuan, Ha Anh. "The Tragedy of Vietnamese Fishermen: The Forgotten Faces of Territorial Disputes in the South China Sea." Asia Journal of Global Studies 5, no. 2 (2013): 94-107.

Zhang, Hongzhou. "Fisheries Cooperation in the South China Sea: Evaluating the Options." Marine Policy 89 (2018): 67-76.

Zou, Keyuan, and Xinchang Liu. "Skip Nav Destination Article Navigation The Legal Status of the U-Shaped Line in the South China Sea and Its Legal Implications for Sovereignty, Sovereign Rights and Maritime Jurisdiction." Chinese Journal of International Law 14, no. 1 (2015): 73 . 